\title{
Back Door Listing: Kewenangan Badan Usaha dan UMKM Untuk Melakukan Initial Public Offering Tanpa Melewati Proses IPO
}

\author{
Yoga Partamayasa \\ yogapartamayasa@outlook.co.id \\ Universitas Airlangga
}

\begin{abstract}
Keywords:
Back Door

Registration;

MSME; Capital

Market; Stocks.

Abstract

The application of the concept of capital market law is very closely related to the concept of limited corporate law. Because in the process of listing shares on a stock exchange, one of these important requirements must be provided by a limited company. However, the cost to create a company is not cheap. Coupled with the cost of listing shares, due diligence is not small and a long process. This replaces companies that enter the stock exchange which are postponed by companies with large capitalization. While startups and MSMEs are preventing it from being possible to keep their shares on the stock exchange. Back Door Concept Listing is a solution that can be done for companies with small capitalization and / or MSMEs to list their shares on the stock exchange. It is expected that with the Back Door Policy, the listing of shares listing activities in the stock exchange is no longer necessary only by companies with large capitalization, but also provides opportunities for companies that have small capitalization and / or MSMEs to enter the Capital Market.
\end{abstract}

Kata Kunci: $\quad$ Abstrak

Back Door Listing; Konsep hukum pasar modal sangat erat kaitannya dengan konsep hukum UMKM; Pasar perseroan terbatas. Karena dalam melakukan proses pencatatan saham di bursa Modal; Saham. efek, salah satu persyaratan utamanya bahwa usaha tersebut harus berbentuk perseroan terbatas. Namun biaya untuk membuat sebuah perseroan tidak murah. Ditambah lagi dengan biaya pencatatan saham, biaya Due Diligence yang tidak sedikit serta prosesnya yang panjang. Hal ini mengakibatkan perusahaan yang masuk ke bursa efek didominasi oleh perusahaan dengan kapitalisasi besar. Sedangkan perusahaan startup dan usaha UMKM hampir tidak mungkin untuk dapat mencatatkan sahamnya di bursa efek. Konsep Back Door Listing adalah solusi yang dapat dilakukan bagi perusahaan dengan kapitalisasi kecil dan/ atau UMKM untuk mencatatkan sahamnya di bursa efek. Diharapkan dengan mekanisme Back Door Listing kegiatan pencatatan saham di bursa efek sudah tidak didominasi lagi hanya oleh perusahaan dengan kapitalisasi besar, namun juga dapat memberikan kesempatan bagi perusahaan yang memiliki kapitalisasi kecil dan/atau UMKM untuk masuk ke Pasar Modal.

\section{Pendahuluan}

Copyright $\odot 2020$ Universitas Airlangga

Dalam konsep badan usaha, dikenal 2 kategori, yaitu badan usaha berbadan hukum dan badan usaha tidak berbadan hukum. Menurut E. Utrecht, badan hukum (rechtpersoon), yaitu badan yang menurut hukum berkuasa (berwenang) menjadi pendukung hak, selanjutnya dijelaskan bahwa badan hukum adalah setiap 
pendukung hak yang tidak berjiwa atau yang lebih tepat bukan manusia. ${ }^{1}$ Badan usaha berbadan hukum yaitu PT (Perseroan Terbatas), yayasan, dan koperasi. ${ }^{2}$ Sedangkan badan usaha non badan hukum adalah persekutuan, perkumpulan, firma, persekutuan komanditer, dan persekutuan komanditer atas saham. ${ }^{3}$

Sebagaimana yang dimaksud dalam Undang-Undang Nomor 8 Tahun 1995 menyatakan perusahaan yang ingin mencatatkan sahamnya di bursa efek wajib berstatus perseroan terbatas. Sedangkan tidak semua UMKM mampu untuk mendirikan perseroan terbatas. Untuk melakukan IPO, perseroan harus mengeluarkan biaya yang besar. Biaya-biaya tersebut berupa Biaya Pencatatan Saham. Sebagaimana Peraturan I-A Tentang Pencatatan Saham Dan Efek Bersifat Ekuitas Selain Saham, Diterbitkan Oleh Perusahaan Tercatat, menyuatakan bahwa Perusahaan Tercatat wajib membayar biaya pencatatan awal pada saat awal pencatatan dan biaya pencatatan tahunan setiap tahun, serta biaya pencatatan saham tambahan apabila mencatatkan saham tambahan. ${ }^{4}$ Perusahaan juga diharuskan menganggarkan biaya lain berupa : biaya jasa akuntan publik, konsultan hukum, notaris, Underwriter, pencatatan saham, appraisal administrasi saham, penitipan kolektif saham, iklan, pencetakan prospektus, dan lain-lain. ${ }^{5}$ Dalam proses IPO (Initial Public Offering), perusahaan juga diharuskan untuk melalui proses sebagaimana diatur dalam Peraturan Badan Pengawas Pasar Modal dan Lembaga Keuangan IX.A.2 tentang Tata Cara Pendaftaran Dalam Rangka Penwaran Umum yaitu berupa: Penunjukan Underwriter dan Persiapan Dokumen, Penyampaian Permohonan Pencatatan Saham ke Bursa Efek Indonesia, Penyampaian Pernyataan Pendaftaran ke OJK, Penawaran Umum Saham kepada Publik, serta Pencatatan dan Perdagangan Saham Perusahaan di Bursa Efek Indonesia. ${ }^{6}$

\footnotetext{
${ }^{1}$ Chidir Ali, Badan Hukum (Alumni 1991).

2 M. Yahya Harahap, Hukum Perseroan Terbatas (Sinar Grafika 2015).[33].

3 ibid.[1-21].

${ }^{4}$ Laras Amyati Kusumastuti, ‘Perlindungan Hukum Notaris Pasar Modal Terhadap Backdoor Listing (Studi Kasus Backdoor Listing PT Indonesia Airasia Terhadap PT Rimau Multi Putra Pratama Tbk)' (Fakultas Hukum Universitas Islam Indonesia 2019).[ 3-4].

5 ibid.

6 ibid.
} 
Biaya serta prosedur di atas sangat sulit untuk dipenuhi oleh perusahaan dengan kapitalisasi kecil dan/atau UMKM. Sedangkan tidak selalu perusahaan dengan kapitalisasi kecil dan/atau UMKM memiliki kinerja buruk dan tidak selalu pula perusahaan dengan kapitalisasi besar memiliki kinerja baik. Maka dari itu, untuk memberikan kesempatan yang sama bagi para pelaku usaha untuk melakukan IPO, maka tulisan ini hadir dengan menggagas Back Door Listing : Kewenangan Badan Usaha Dan UMKM Untuk Melakukan Initial Public Offering Tanpa Melewati Proses IPO. Dengan proses Back Door Listing semua pelaku usaha, bahkan usaha orang perseorangan bisa melantai di bursa dikarenakan proses Back Door Listing ini melibatkan proses pengambilalihan sebagaimana dalam UndangUndang Nomor 40 Tahun 2007.

\section{Metode Penelitian}

Sebagaimana yang dikatakan oleh Peter Mahmud Marzuki, pendekatanpendekatan yang dapat digunakan dalam metode penelitian hukum adalah “pendekatan undang-undang (statute approach), pendekatan kasus (case approach), pendekatan komparatif (comparative approach), dan pendekatan konseptual (conseptual approach)". ${ }^{7}$

Dalam penulisan ini, penulis menggunakan beberapa pendekatan masalah sebagai berikut:

1. Statute Approach yaitu dilakukan dengan menelaah peraturan perundangundangan yang berlaku dan yang berkaitan dengan isu hukum yang sedang diangkat oleh Penulis dengan cara mencari ratio legis dan dasar ontologis Back Door Listing. ${ }^{8}$

2. Conseptual Approach yaitu dilakukan dengan menelaah sebuah konsep melalui kajian-kajian terhadap doktrin yang berkembang dalam ilmu hukum. Dalam hal ini penulis berusaha untuk mengkaji konsepsi Back Door Listing.

\footnotetext{
7 Peter Mahmud Marzuki, Penelitian Hukum (Kencana Prenada Media Group 2011).[133].

8 ibid. [93].
} 


\section{Hasil dan Analisis}

David Logan Scott menyatakan pengertian backdoor listing sebagai berikut: ${ }^{9}$ "acquisition and merger with a listed company by an unlisted company in order to gain a listing on a securities exchange".

Prof. Morris Viljoen menyatakan pengertian backdoor listing sebagai berikut:10 "A method of listing a business on the stock market without going through an IPO". Prof. Carlos Correia dalam bukunya "Financial Management" menyatakan pengertian backdoor listing adalah:11 "A company obtains a listing indirectly by using an existing listed company to achieve a listing".

Bagi pengusaha, baik berbentuk badan hukum, perorangan, atau badan usaha non badan hukum, alternatif pendanaan yang dapat digunakan untuk mendanai usaha yaitu: ${ }^{12}$

a. Mencari pinjaman/tambahan pinjaman;

b. Partner untuk merger;

c. Menjual perusahaan/menutup perusahaan; atau

d. Mencari tambahan modal dengan mencari pihak lain yang mau ikut menanam modal pada perusahaan.

Dalam hal ini mekanisme pendanaan oleh investor melalui pasar modal adalah sebuah mekanisme yang paling banyak memberikan keuntungan bagi para stakeholder, dikarenakan disamping memperoleh dana tambahan, perusahaan juga akan memperoleh manfaat lainnya seperti branding, dan jaringan antar perusahaan di pasar modal. Selain keuntungan tersebut, terdapat resiko dalam menjalankan perusahaan publik, yaitu: ${ }^{13}$

a. Butuh biaya yang sangat besar untuk mendaftarkan efek ke IPO sebagai syarat tercatatnya suatu perusahaan di bursa saham sebagai perusahaan publik;

b. Meningkatkan pengeluaran dan pemaparan potensi kewajiban berkenaan dengan registrasi dan laporan berkala;

c. Hilangnya control terhadap perusahaan karena terjadi dilusi kepemilikan

9 David Logan Scott, Wall Street Words: An A To Z Guide To Investment Terms For Today's Investor (Third Edition, Houghton Mifflin Company 2003).[22].

${ }_{10}$ MJ Viljoen and N Sibiya, Longman Dictionary of Financial Terms (Pearson 2007).[10].

11 Carlos Correia dkk, Financial Management (Juta and Company Ltd 2007).[10]. 1996).[11].

12 Asril Sitompul, Pasar Modal Penawaran Umum Dan Permasalahannya (Citra Aditya Bakti

${ }_{13}$ M Irsan Nasarudin, Aspek Hukum Pasar Modal Indonesia (Kencana 2008). [216]. 
saham;

d. Keharusan mengumumkan besarnya pendapatan perusahaan dan pembagian deviden;

e. Efek yang diterbitkan mungkin saja tidak terserap oleh masyarakat sesuai dengan perhitungan perusahaan.

Terdapat lima keuntungan bagi perusahaan publik yang tercatat di bursa saham menurut David N. Fieldman, yaitu: ${ }^{14}$

"Advantages of Being Public In general, there are fi ve major advantages to being public: easier access to capital, greater liquidity, ability to grow through acquisitions or strategic partnerships, ability to use stock options to attract and retain senior executives, and increased shareholder confidence in management".

Namun sebuah perusahaan dapat masuk ke pasar modal setelah perusahaan tersebut melakukan Initial Public Offering. Initial Public Offering atau IPO di Indonesia secara tegas telah dijelaskan di dalam Undang-Undang Nomor 8 Tahun 1995 tentang Pasar Modal Pasal 1 angka 13 menyatakan Pasar modal adalah kegiatan yang bersangkutan dengan penawaran umum dan perdagangan efek, perusahaan publik yang berkaitan dengan efek yang diterbitkannya, serta lembaga dan profesi yang berkaitan dengan efek. Alternatif untuk perusahaan selain menjadikan perusahaan sebagai perusahaan publik yang tercatat di bursa, ada beberapa pilihan strategi yang umum ditempuh oleh pelaku usaha untuk mengembangkan dan memantapkan perusahaannya adalah sebagai berikut: ${ }^{15}$

1. Stabilisasi dan optimalisasi daya internal secara efektif dan efisien tanpa melibatkan unsur-unsur di luar perushaan (kecuali pinjaman dari Bank);

2. Melibatkan partisipasi unsur-unsur yang ada di luar perusahaan, antara lain melalui joint venture, merger, akuisisi, konsolidasi, menggalang kemitraan dan lain sebagainya; dan

3. Menggabungkan kedua strategi 1 (satu) dan 2 (dua), yaitu dengan melakukan optimalisasi sumber daya internal perusahaan serta memanfaatkan sumber daya eksternal dalam rangka pemgembangan perusahaan. 2006).[7].

${ }_{14}$ David N.Fieldman, Reverse Mergers: Taking a Company Without an IPO (Bloomberg Press

${ }^{15}$ M Irsan Nasaruddin, Aspek Hukum Pasar Modal Indonesia (Kencana 2008).[216]. 
Atas dasar angka 2 diatas, maka perusahaan dengan kapitalisasi kecil atau usaha UMKM dapat masuk ke pasar modal tanpa melalui mekanisme penawaran umum. Hal ini disebabkan untuk melakukan proses penawaran umum membutuhkan biaya yang sangat mahal. Biaya yang harus dikeluarkan pada saat melakukan penawaran umum tersebut meliputi biaya proses, pelaksanaan dan biaya-biaya yang akan dikeluarkan setelah terjadinya penawaran umum. ${ }^{16}$ Sehingga atas begitu banyak perusahaan yang ingin melakukan penawaran umum, timbulah cara lain untuk mendapatkan keuntungan di pasar modal sebagaimana perusahaan publik namun tanpa melakukan go public, melalui sebuah mekanisme yang disebut Backdoor listing..$^{17}$ Backdoor listing adalah suatu upaya yang dilakukan perusahaan untuk mendapatkan akses ke pasar modal dan bursa dengan segala fasilitasnya secara tidak langsung, tetapi hal ini dilakukan tidak melalui proses penawaran umum (IPO) melainkan melalui perusahaan lain yang sudah tercatat di bursa. ${ }^{18}$

Di Indonesia, ketentuan dan tata cara Backdoor listing belum diatur secara tegas di dalam peraturan perundang-undanggan manapun. Namun, Backdoor listing tidak dilarang dalam hukum di Indonesia. Tata cara Backdoor listing dilakukan melalui proses akuisisi antara perusahaan yang telah ada di bursa dengan perusahaan yang belum masuk di bursa, dengan tujuan perusahaan yang belum masuk di bursa dapat masuk di bursa efek tanpa harus melewati proses IPO. Dikarenakan Backdoor listing dilakukan melalui proses akuisisi, maka proses serta tata cara Backdoor listing tunduk pada Undang-Undang Nomor 40 Tahun 2007 tentang Perseroan Terbatas. Sebagaimana yang dimaksud dalam pasal 1 angka 7 UUPT ditentukan bahwa perseroan terbuka adalah perseroan terbatas publik atau perseroan terbatas yang melakukan penawaran umum saham sesuai dengan ketentuan peraturan perundang-undangan di bidang pasar modal. Mekanisme strategi backdoor listing melalui akuisisi terbagi menjadi 2 cara, yaitu: ${ }^{19}$

\footnotetext{
${ }_{16}$ Asril Sitompul., Op., Cit., (n 12).[18] 2006).[7].

17 David N.Feldman, Reverse Mergers : Taking A Company Without an IPO (Bloomberg Press

${ }^{18}$ Hasan Zein, ‘Backdoor Listing Di Bursa Perlu Segera Diatur' Bisnis Indonesia (1997).[7].

19 'Backdoor Listing: Jalan Pintas Menjadi Perusahaan Publik' [2000] Jurnal Pasar Modal Indonesia.[66].
} 
a. Perusahaan tertutup mengakuisisi perusahaan publik, dengan membeli seluruh atau sebagian besar saham perusahaan yang telah masuk bursa atau listing di pasar modal, baik secara seketika atau bertahap;

b. Perusahaan publik mengakuisisi perusahaan tertutup. Setelah dilakukannya akuisisi tersebut, maka pihak pengendali baru atas perusahaan publik (yang melakukan backdoor listing) melakukan restrukturisasi.

Di dalam Undang-Undang Nomor 40 Tahun 2007, akuisisi juga dikenal dengan istilah pengambilalihan. Sebagaimana yang dimaksud dalam Pasal 1 angka 11 Undang-Undang a quo menyatakan bahwa Pengambilalihan adalah perbuatan hukum yang dilakukan oleh badan hukum atau orang perseorangan untuk mengambil alih saham Perseroan yang mengakibatkan beralihnya pengendalian atas Perseroan tersebut. Sebagaimana yang dimaksud dalam Pasal 26 UndangUndang a quo, perseroan dalam melaksanakan pengambilalihan harus melakukan perubahan terhadap anggaran dasar yang berlaku sejak tanggal:

a. persetujuan Menteri;

b. kemudian yang ditetapkan dalampersetujuan Menteri; atau

c. pemberitahuan perubahan anggaran dasar diterima Menteri, atau tanggal kemudian yang ditetapkan dalam akta Penggabungan atau akta Pengambilalihan.

Dalam melaksanakan pengambilalihan untuk proses backdoor listing maka harus memperhatikan kepentingan pemegang saham masing masing perusahaan, baik yang akan mengambilalih maupun yang akan diambilalih,yaitu dengan meminta kepada Perseroan agar sahamnya dibeli dengan harga yang wajar apabila yang bersangkutan tidak menyetujui tindakan Perseroan yang merugikan pemegang saham atau Perseroan sebagaimana yang dimaksud dalam Pasal 62 ayat (1) Undang-Undang Nomor 40 Tahun 2007. Rapat RUPS wajib dilakukan dalam melaksanakan pengambilalihan dengan ketentuan dalam rapat paling sedikit 3/4 (tiga perempat) bagian dari jumlah seluruh saham dengan hak suara hadir atau diwakili dalam RUPS dan keputusan adalah sah jika disetujui paling sedikit 3/4 (tiga perempat) bagian dari jumlah suara yang dikeluarkan, kecuali anggaran 
dasar menentukan kuorum kehadiran dan/atau ketentuan tentang persyaratan pengambilan keputusan RUPS yang lebih besar. ${ }^{20}$ Sebagaimana yang dimaksud dalam Pasal 125 ayat (1) Undang-Undang a quo menyatakan Pengambilalihan dilakukan dengan cara pengambilalihan saham yang telah dikeluarkan dan/atau akan dikeluarkan oleh Perseroan melalui Direksi Perseroan atau langsung dari pemegang saham. Sebagaimana yang dimaksud dalam Pasal 125 ayat (2) undangundang a quo menyatakan subyek yang dapat melakukan pengambilalihan adalah badan hukum atau orang perseorangan. Disinilah letak kesempatan bagi perusahaan rintisan (startup) maupun Usaha Mikro Kecil dan Menengah (UMKM) untuk melaksanakan backdoor listing melalui proses pengambilalihan karena cukup dengan orang perseorangan (tanpa harus mendirikan badan hukum/ badan usaha baru), sebuah usaha sudah dapat ada di bursa efek. Dalam hal orang perseorangan sebagai pemilik sebuah usaha apapun bentuk badan usahanya, untuk dapat melantai di bursa efek maka hal yang harus dipersiapkan hanyalah modal untuk membeli saham perusahaan terbuka yang akan diambil alih serta memperhatikan kepentingan masyarakat dan persaingan sehat dalam melakukan usaha sebagaimana dimaksud dalam Pasal 126 ayat (1) huruf c Undang-Undang $a$ quo. Cukup dengan 2 syarat sebagaimana dimaksud di atas, maka sesungguhnya UMKM atau perusahaan stratup sudah bisa melantai di bursa efek. Meskipun sebagaimana yang dimaksud dalam Pasal 6 ayat (1) Undang-Undang Nomor 8 Tahun 1995 tentang pasar modal menyatakan bahwa hanya perseroan yang dapat menyelenggarakan kegiatan usaha sebagai Bursa Efek yang telah memperoleh izin usaha dari bapepam, namun hal ini tidak perlu dilakukan ketika UMKM atau badan usaha ingin melantai di bursa melalui mekanisme pengambilalihan. Sebab dalam pengambilalihan, sudah ada perusahaan yang sudah tercatat di bursa efek. Penulis memberikan perumpamaan seperti membeli tanah yang telah memiliki sertifikat, maka pembeli tinggal melakukan balik nama dari penjual ke pembeli. Hal ini berbeda dengan proses membeli tanah yang belum memiliki sertifikat,

${ }^{20}$ Undang-Undang Nomor 40 Tahun 2007 tentang Perseroan Terbatas, Ps. 89 ayat (1). 
dimana tanah harus didaftarkan secara sistematik mulai dari proses yang panjang yaitu pengukuran, pengumuman di media, dan lain sebagainya.

Dalam akuisisi dalam rangka Back Door Listing dilakukan dengan mekanisme pembelian saham perusahaan terbuka, untuk mengambil alih perusahaan lain dengan cara membeli saham perusahaan tersebut. ${ }^{21}$

\section{Kesimpulan}

Tata cara Backdoor listing dilakukan melalui proses akuisisi antara perusahaan yang telah ada di bursa dengan perusahaan yang belum masuk di bursa, dengan tujuan perusahaan yang belum masuk di bursa dapat masuk di bursa efek tanpa harus melewati proses IPO. Dikarenakan Backdoor listing dilakukan melalui proses akuisisi, maka proses serta tata cara Backdoor listing tunduk pada Undang-Undang Nomor 40 Tahun 2007 tentang Perseroan Terbatas dengan mekanisme strategi backdoor listing melalui akuisisi terbagi menjadi 2 cara, yaitu ${ }^{22}$ :

a. Perusahaan tertutup mengakuisisi perusahaan publik, dengan membeli seluruh atau sebagian besar saham perusahaan yang telah masuk bursa atau listing di pasar modal, baik secara seketika atau bertahap;

b. Perusahaan publik mengakuisisi perusahaan tertutup. Setelah dilakukannya akuisisi tersebut, maka pihak pengendali baru atas perusahaan publik (yang melakukan backdoor listing) melakukan restrukturisasi.

Sebagaimana yang dimaksud dalam Pasal 26 Undang-Undang a quo, perseroan dalam melaksanakan pengambilalihan harus melakukan perubahan terhadap anggaran dasar yang berlaku sejak tanggal:

a. Persetujuan Menteri;

b. Kemudian yang ditetapkan dalampersetujuan Menteri; atau

c. Pemberitahuan perubahan anggaran dasar diterima Menteri, atau tanggal kemudian yang ditetapkan dalam akta Penggabungan atau akta Pengambilalihan.

\footnotetext{
${ }^{21}$ Kamaludin, Karona Cahya Susena, Dan Berto Usman, Restrukturisasi, Merger, E Akuisisi (Mandar Maju Bandung 2015).[29].

22 Hasan Zein (n 18)., Op Cit.[66].
} 
Sebagaimana yang dimaksud dalam Pasal 125 ayat (2) undang-undang $a$ quo menyatakan subyek yang dapat melakukan pengambilalihan adalah badan hukum atau orang perseorangan. Disinilah letak kesempatan bagi perusahaan rintisan (startup) maupun Usaha Mikro Kecil dan Menengah (UMKM) untuk melaksanakan backdoor listing melalui proses pengambilalihan karena cukup dengan orang perseorangan (tanpa harus mendirikan badan hukum/badan usaha baru), sebuah usaha sudah dapat ada di bursa efek. Dalam hal orang perseorangan sebagai pemilik sebuah usaha apapun bentuk badan usahanya, untuk dapat melantai di bursa efek maka hal yang harus dipersiapkan hanyalah modal untuk membeli saham perusahaan terbuka yang akan diambil alih serta memperhatikan kepentingan masyarakat dan persaingan sehat dalam melakukan usaha sebagaimana dimaksud dalam Pasal 126 ayat (1) huruf c Undang-Undang $a$ quo. Cukup dengan 2 syarat sebagaimana dimaksud di atas, maka sesungguhnya UMKM atau perusahaan stratup sudah bisa melantai di bursa efek.

\section{Daftar Bacaan}

\section{Buku}

Asril Sitompul, Pasar Modal Penawaran Umum Dan Permasalahannya (Citra Aditya Bakti 1996).

Chidir Ali, Badan Hukum (Alumni 1991).

Carlos Correia dkk, Financial Management (Juta and Company Ltd 2007).

David Logan Scott, Wall Street Words: An A To Z Guide To Investment Terms For Today's Investor (Third Edition, Houghton Mifflin Company 2003).

David N.Fieldman, Reverse Mergers: Taking a Company Without an IPO (Bloomberg Press 2006).

Hasan Zein, 'Backdoor Listing Di Bursa Perlu Segera Diatur' Bisnis Indonesia (1997).

Kamaludin, Karona Cahya Susena, Dan Berto Usman, Restrukturisasi, Merger, \& Akuisisi (Mandar Maju Bandung 2015). 
M Irsan Nasaruddin, Aspek Hukum Pasar Modal Indonesia (Kencana 2008).

MJ Viljoen and N Sibiya, Longman Dictionary of Financial Terms (Pearson 2007).

M. Yahya Harahap, Hukum Perseroan Terbatas (Sinar Grafika 2015).

Peter Mahmud Marzuki, Penelitian Hukum (Kencana 2011).

Jurnal

'Backdoor Listing : Jalan Pintas Menjadi Perusahaan Publik' [2000] Jurnal Pasar Modal Indonesia.

\section{Penelitian}

Laras Amyati Kusumastuti, 'Perlindungan Hukum Notaris Pasar Modal Terhadap Backdoor Listing (Studi Kasus Backdoor Listing PT Indonesia Airasia Terhadap PT Rimau Multi Putra Pratama Tbk)' (Fakultas Hukum Universitas Islam Indonesia 2019).

How to cite: Yoga Partamayasa, 'Back Door Listing: Kewenangan Badan Usaha Dan UMKM Untuk Melakukan Initial Public Offering Tanpa Melewati Proses IPO' (2020) Vol. 3 No. 3 Media Iuris. 
--Halaman ini sengaja dibiarkan kosong-- 